\title{
DAMPAK PERILAKU CYBER-SEX DIKALANGAN GENERASI MILLENIAL PADA REMAJA DI MAN KOTA TEGAL
}

\section{THE IMPACT OF CYBER-SEX BEHAVIOR AMONG MILLENNIAL GENERATIONS IN ADOLESCENTS IN MAN TEGAL CITY}

\author{
Evi Zulfiana, RiskaArsita Harnawati \\ Politeknik Harapan BersamaTegal \\ Korespondensi: evi.zulfiana33@gmail.com
}

\begin{abstract}
The Ministry of Communication and Informatics in 2012 found that $80 \%$ of respondents surveyed were using the Internet. The presence of Internet technology has opened up new forms of sexual behavior such as Cyber-Sex. Cyber-Sex is two or more individuals engaged in simultaneous, real-time, sexual or erotic conversations using online media (e.g. chatroom, instant messaging, and new forms of mobile-based applications).

The purpose of this study is to find out the impact of Cyber-sex behavior among Millennials in adolescents in Madrasah Aliyah Negeri (MAN) Tegal City Area

The research method used is qualitative research, while the approach used in this research is phenomenological, data retrieval is carried out with in-depth interview techniques according to guidelines. The results of the info obtained and then recorded and made land records. To prevent subjectivity.

The results of interviews with respondents obtained information about the impact of influence behavior on cybersex is that all respondents know porn sites at the age of 14 years old teenage girls. The site that the majority saw photos or pictures of beautiful, sexy and some got to look to the more distant that is sexual intercourse.

the results of this study found that adolescents tend to access porn sites at the age of 15 17 years, teens visit porn sites regarding pretty, sexy, and BF movies, communicate with girlfriends through chats and fucking calls by discussing sex, impeachment after watching porn sites with girlfriends kissing, cuddling and necking, respondents often masturbating after watching/ viewing porn sites, curiosity and curiosity that causes respondents to want to open porn sites, within a week respondents access 3-4 times and 1-2 hours per day, after watching porn sites respondents feel satisfied and entertained.
\end{abstract}

Keywords : Behavioral Impact, Cyber-Sex

\footnotetext{
ABSTRAK

Kementerian Komunikasi dan Informatika tahun 2012 menemukan bahwa 80\% responden yang disurvei merupakan penggunaan Internet. Kehadiran teknologi Internet telah membuka munculnya bentuk-bentuk perilaku seksual baru seperti Cyber-Sex. Cyber-Sex adalah dua atau lebih individu yang terlibat dalam percakapan secara simultan, real-time, berinteraksi sexual atau erotis dengan menggunakan media online (misalnya chatroom, instant messaging, dan bentuk-bentuk baru dari aplikasi berbasis ponsel).
} 
Tujuan dari penelitian ini adalah untuk mengetahui dampak perilaku Perilaku Cyber-sex dikalangan Generasi Millennial pada remaja di Madrasah Aliyah Negeri (MAN) Wilayah Kota Tegal.

Metode penelitian yang digunakan yaitu penelitian kualitatif, sedangkan pendekatan yang digunakan dalam penelitian ini adalah fenomenologis, Pengambilan data dijalankan dengan teknik indepth interview sesuai pedoman. Hasil info yang didapat lalu direkam dan dibuat catatan lahan untuk mencegah terjadinya subyektifitas.

Hasil wawancara dengan responden didapatkan informasi tentang Dampak perilaku pengaruh tentang cyber sex adalah semua responden mengenal situs porno pada usia remaja putri 14 tahun remaja laki- laki 17 Tahun. Situs yang dilihat mayoritas melihat foto atau gambar gambar wanita cantik, seksi, telanjang dan ada yang sampai melihat ke yang lebih jauh yaitu hubungan seksual.

Hasil penelitian ini didapatkan bahwa remaja kecenderungan mengakses situs porno pada pada usia 15-17 tahun, remaja mengunjungi situs porno mengenai gambar-gambar waita cantik, seksi dan film BF, komunikasi dengan pacar melalui chating dan vidio call dengan membahasan sex, pelampiasan setelah menonton situs porno dengan pacar ciuman, berpelukan dan sampai nekcing, responden sering onani setelah menonton/ melihat situs porno, perasaan penasaran dan rasa ingin tahu yang menyebabkan responden ingin membuka situs porno, dalam seminggu responden mengakses 3-4 kali dan lamanya 1-2 jam perhari, setelah menonton situs porno responden merasa puas dan terhibur.

\section{Kata Kunci : Dampak Perilaku, Cyber-Sex}

\section{PENDAHULUAN}

Salah satu produk teknologi informasi adalah internet, tehnologi internet dewasa ini semakin berkembang pesat bahkan dianggap sebagai media yang sangat penting dalam pengembangan pengetahuan, perluasan usaha maupun hiburan. Generasi millennial merupakan sebuah terminologi yang akhir-akhir ini banyak diperbincangkan. Generasi, sebagaimana didefinisikan oleh beberapa analis, adalah sekelompok orang yang dibentuk oleh sejarah, memiliki karakteristik yang berbeda satu dengan lainnya terutama dalam perbedaan tahun kelahiran, serta telah mengalami perkembangan zaman.

Stafford \& Griffis (2008) mengungkapkan bahwa generasi millennial yang juga dikenal sebagai Generasi Y, merupakan kelompok demografis (cohort) setelah Generasi X yang lahir di antara tahun 1980 hingga 2000. Artinya, generasi millennial adalah generasi muda yang saat ini berusia antara 18-38 tahun.

Hasil survei Kementerian Komunikasi dan Informatika tahun 2012 menemukan bahwa 80\% responden yang disurvei merupakan penggunaan Internet. Kehadiran teknologi Internet telah membuka 
munculnya bentuk-bentuk perilaku seksual baru seperti Cyber-Sex.

Cyber-Sex adalah dua atau lebih individu yang terlibat dalam percakapan secara simultan, real-time, berinteraksi sexual atau erotis dengan menggunakan media online (misalnya charroom, instant messaging, dan bentuk-bentuk baru dari aplikasi berbasis ponsel).

Studi mengenai generasi millennial terutama di Amerika salah satunya pada tahun 2010, digawangi oleh Pew Research Center yang merilis laporan riset dengan judul Millennials: A Portrait of Generation Next. Berdasar data empiris dari riset tersebut dan sumber-sumber lain mengenai kajian literatur generasi, sekaligus sebagai topik yang menarik dalam berbagai survei, laporan, dan artikel berita, Stafford \& Griffis (2008) setidaknya mencatat dan menelaah literatur untuk mengeksplorasi beberapa karakteristik unik generasi ini dibanding generasi lainnya. Beberapa karakteristik utama millennial yang diidentifikasi seperti loyalitas kelompok dan persepsi yang kuat terhadap hak, bergantung pada influencer sosial dan jaringan untuk membuat keputusan hidup yang penting, pencapaian pendidikan merupakan prioritas tinggi, dan penggunaan teknologi dalam cara hidup dan berinteraksi merupakan karakteristik millennial ketika di rumah, di tempat kerja, bahkan saat bermain. Survei juga menunjukkan bahwa generasi millennial berusaha mengubah dunia di sekitarnya baik di tempat kerja dan di arena sosial dan politik.

Berdasarkan fenomena di atas, maka peneliti tertarik untuk melakukan penelitian dengan tujuan untuk mengetahui dampak perilaku Perilaku Cyber-sex dikalangan Generasi Millennial pada remaja di Madrasah Aliyah Negeri (MAN) Wilayah Kota Tegal.

\section{METODE}

Desain penelitian ini adalah penelitian kualitatif, sedangkan pendekatan yang digunakan dalam penelitian ini adalah fenomenologis. Populasi pada penelitian ini adalah remaja di Madrasah Aliyah Negeri (MAN) Wilayah Kota Tegal. Teknik pengambilan sampel adalah sistem accidental sampling. Responden remaja kelas XI Madrasah Aliyah Negeri (MAN) berjumlah 4 remaja siswa dan siswi. Sasaran dilakukan pada remaja yang mempunyai hp android karena kemungkinan siswa dan siswi tersebut mengakses berbagai macam situs online. 
Analisis kualitatif dilakukan dengan cara analisis isi (content analysis) berdasarkan data mengenai studi fenomenologi persepsi remaja tentang perilaku cyber sex yang diperoleh dari hasil wawancara mendalam terhadap remaja di Madrasah Aliyah Negeri (MAN) Wilayah Kota Tegal.

\section{HASIL DAN PEMBAHASAN}

Semua informasi baik data, pernyataan dan hasil yang disampaikan responden ditulis selengkap-lengkapnya sesuai catatan dan hasil rekaman. Data yang telah ditulis kemudian dicermati berkali-kali terkait dampak perilaku cyber-Sex dikalangan remaja di Madrasah Aliyah Negeri (MAN) kota tegal. hasil data seperti tabel berikut:

\section{Mengenal situs porno}

Saya mengenal situs porno pada awal masuk MAN karena penasaran seperti apa isinya dan apa saja yang ada disana (RI).

Hmmm...hehehe...pas SMP bu...di ajari sma teman di rumah, teman lebih tua SMA, akhirnya saya penasaran, trus buka situsnya (R2).

Sudah 2 tahunan bu, buka-buka yang kaya gitu, pertama penasaran. (R3)

Buka situs porno baru-baru ini bu,,pertama ya karena penasaran isinya. (R4)
Pada prinsipnya 4 responden mempunyai jawaban menganal situs porno pada usia remaja yaitu usia masa remaja awal pada perempuan yaitu 1315 tahun dan pada laki-laki yaitu 15-17 tahun. Pada perkembangan ini remaja mengalami perkembangan fisik remaja diantaranya menurut Piaget (dalam Papalia \& Olds 2001, dalam Jahja, 2012) menambahkan bahwa perubahan pada tubuh ditandai dengan pertambahan tinggi dan berat tubuh, pertumbuhan tulang dan otot, dan kematangan organ seksual dan fungsi reproduksi dan muncul tanda-tanda seks primer dan seks sekunder.

2. Situs porno yang dilihat

Saya melihat situs porno tentang gambar gambar wanita cantik,seksi, sampai melihat film porno(RI)

Buka situs porno ya macem-macem sekalian buka yang banyak biar puas bukanya ada gambar wanita pakai baju seksi sampai liat yang telanjang, ya kadang buka yang lagi begituan..hehehe (R2)

Bukanya banyak bu, ada gambar seksi,gambar wanita cantik cantik ga pake baju,hehehe, gambar lain-lain lah bu pokoknya banyak, buka film BF (R3).

Lihat gambar wanita sing ayu-ayu bu (wanita cantik, seksi, telanjang, banyak bu disitu.(R4

Berdasarkan hasil wawancara dari

4 responden mengenai situs porno 
yang dikunjungi mayoritas remaja jawabannya hampir sama yaitu melihat foto atau gambar-gambar wanita cantik, seksi, telanjang dan ada yang sampai melihat ke yang lebih jauh yaitu hubungan seksual.

3. Komunikasi dengan pacar tentang sex melalui media chating, Hp, Vidio call

Pernah bu, saya kalau telp sama pacar kadang nyerempet 2 tentang sex..hehehe(RI)

Dulu pernah bu,tapi sekarang sudah putus. Ya telp-telpnan bicara $\operatorname{sex}(R 2)$

Tidak punya pacar bu, tapi telp-telp sama teman mengarah tentang $\operatorname{sex}(R 3)$

Pernah bu, bicara seks sama pacar lewat hp.(R4)

Berdasarkan hasil wawancara dari 4 responden mengenai komunikasi dengan pacar tentang sexsual jawabannya hampir sama yaitu pernah komunikasi dengan pacar atau teman yang berhubungan dengan seksual.

4. Pernah masturbasi/onani

Pernah mengalami onani, kalau melihat video porno dan mimpi ketemu cewe canti..hehehe(RI).

Pernah onani, pas mimpi, kalau membayangkan, menghayal tentang seseorang, melihat gambar-gambar cantik (R2)
Sering onani, kalau menonton situs porno yang isisnya wanita-waita seksi,cantik dan tidak pakai baju (R3)

Sering Onani, kalau lihat vidio porno, wanita seksi.(R4).

Berdasarkan hasil wawancara dari 4 responden mengenai masturbasi/ onani jawabannya semua pernah mengalami onani jika melihat situs/media porno.

5. Lama dalam mengakses internet satu minggu

$\begin{array}{lrr}\begin{array}{l}\text { Membuka situs porno } \\ \text { bu..ya..hampir }\end{array} & \begin{array}{l}\text { sering } \\ \text { setiap }\end{array} \\ \begin{array}{l}\text { hari..hehehe..sekitar } \\ \text { perhari }(R 1)\end{array} & 1-2 & \text { jaman }\end{array}$

Ya kadang dalam 1 minggu bisa 4 kali lah bu...lama mengakses 1 jam perhari (R2)

Bisa setiap hari bu bukanya, hehehhe..tergantung bu kalau lg buka film ya bisa lama 2 jam lah bu perhari (R3)

Buka 1 minggu kadang 3-4 kali bu..lama bukanya 1-2 jam an perhari bu $(R 4)$

Berdasarkan hasil wawancara dari 4 responden mengenai lama mengakses porno dalam 1 minggu dan lama mengaksesnya jawaban responden setiap hari dan waktu mengakses antara 1-2 jam perhari.

6. Dalam menonton video porno anda akan terhibur dan merasa puas? 
Kalau lagi banyak pikiran, stress langsung buka situs porno, ya bisa terhibur dan merasa puas bu..(R1)

Ya bu kayane hatinya lega dan puas..(R2)

Kalau lagi ga ada kerjaan, pusing tak buka situs porno bu (R3)

Ya bu saya merasa puas dan terhibur (R4)

Berdasarkan hasil wawancara dari 4 responden mengenai menonton video porno akan merasa terhibur dan merasa puas jawaban responden semuanya merasa terhibur dan puas.

7. Reaksi pertama kali mengetahui tentang adanya situs porno diinternet Pertama buka situs porno hati bergetar bu, ada perasaan takut, tapi juga penasaran, rasa ingin tahu apa yang ada disitu bu, jadi ya tak buka situs pornonya. (RI)

Deg-degan bu pas pertama kali bukanya, tapi pengen liat isinya apa saja $(R 2)$

Rasa penasaran yang pertama kali, pengen liat isinya, pas buka hatinya deg-degan (R3)

Campur aduk rasany bu, rasa penasaran sih bu pertamanya (R4).

Berdasarkan hasil wawancara dari 4 responden mengenai reaksi pertama kali tentang membuka situs porno, jawabannya mayoritas rasa penasaran dan rasa ingin tahu.
8. Faktor apa yang menyebabkan ingin mengakses situs porno

Faktornya ada rasa penasaran, ingin tahu bu, di ajak teman (RI)

Ya rasa penasaran bu, trs temanteman kalau kumpul kadang buka situs ini (R2).

Penasaran bu, pengen liat juga sih bu $(R 4)$

Rasa ingin tahu bu, jadi buka buka internet yang begituan bu(R4)

Berdasarkan hasil wawancara dari 4 responden mengenai faktor yang menyababkan ingin mengakses situs porno, jawabannya semua rsa penasaran dan ingin tahu.

9. Apakah setelah menonton video porno anda melampiaskan dengan pasangan anda?apabila iya mulai kapan dan berapa kali dalam 1 minggu.

Ya perasaan ada, tapi takut, paling kalau ketemu pacar hanya pelukan, ciuman tidak sampai ke hubungan seksual.(RI)

Dulu pas punya pacar tidak melampiaskan ke pacar bu..takut, paling ya ciuman, pelukan. (R2)

Tidak sampai sejauh itu bu, paling hanya ciuman, pelukan, membelai rambut ( $R 3)$.

Hanya ciuman, pelukan bu, ya sempat kearah necking..heheh (R4) 
Berdasarkan hasil wawancara dari 4 responden mengenai pelampiasan setelah menonton video porno jawaban responden hanya sebatas ciuman, berpelukan dan ada yang sampai necking.

Perkembgan internet yang sangat pesat dengan segala kelebihan dan manfaatnya ternyata juga menghadirkan masalah lain, salah satunya adalah fenomena cybersex. Cybersex adalah aktivitas-aktivitas yang mengandung unsur porno didalamnya, seperti melihat gambar- gambar erotis, terlibat dalam chatting tentang seks, saling tukar menukar gambar atau pesan email tentang seks (Cooper, 2002). Fenomena ini didukung hasil riset yang dilakukan terhadap 1.200 orang pelajar SMP dan SMA di 12 kota di Indonesia, 97\% pelajar pernah dan suka membuka situs porno. Fenomena cybersex ini memiliki dampak yang negatif bagi remaja. Ketua Komisi Fatwa MUI kota Pekanbaru menyebutkan bahwa tontonan televisi, video, bahkan internet memiliki pengaruh besar yang menyebabkan penyimpangan seksual kian menjadijadi saat ini. Belum lagi dengan mudahnya saat ini mendapatkan video porno, baik berupa $\mathrm{CD}$ maupun melihatnya di internet. Prihartini,
Nuryoto, dan Aviatin (2002) dalam penelitiannya mengatakan bahwasannya dorongan seksual yang meningkat dan rasa ingin tahu yang besar tentang seksualitas seringkali membawa remaja yang sedang berada dalam posisi rentan kepada kasus-kasus "keterlanjuran". Masalah-masalah "keterlanjuran" akibat seksualitas pada remaja dapat berupa kehamilan pranikah, perilaku seksual remaja yang semakin bebas, dan penularan penyakit seksual. Fenomena tersebut juga diperkuat oleh pemberitaan di media massa mengenai maraknya perilaku seksual bebas di kalangan remaja. Hal ini di dukung oleh penelitian Daneback, Cooper, dan Mansson (dalam Sari dan Purba, 2012) yang mengatakan bahwa yang paling banyak menggunakan internet untuk tujuan seksual adalah remaja. Rasa ingin tahu yang besar mengenai seksualitas menyebabkan remaja mencari sumber informasi mengenai seksualitas. Penelitian Harmaini dan Mukhlis (2010) mencatat bahwa remaja di Pekanbaru mendapatkan informasi mengenai seksualitas terbanyak ke dua adalah melalui internet, lalu $\mathrm{dvd} / \mathrm{vcd}$, dan HP. Media merupakan sumber informasi yang mudah di akses dan didapatkan, namun tidak dapat 
dipertanggung jawabkan dampaknya karena remaja dapat salah memberikan arti terhadap apa yang dilihat, sehingga memunculkan dampak yang negatif. Fenomena seksual yang pelakunya didominasi para remaja ini merupakan suatu masalah yang sangat serius. Kerentanan remaja dalam menghadapi masalah seksualitas timbul seiring dengan perkembangan remaja yang sedang dalam masa transisi. Masa transisi merupakan masa peralihan. Pada masa ini baik laki-laki ataupun perempuan mengalami perkembangann fisik dan psikis dengan ciri yang berbeda. Hurlock menyatakan awal perkembangan remaja terjadi pada periode pubertas. Pada periode ini terjadi perkembangan alat-alat dan hormon-hormon seksualitas yang akan mempengaruhi kondisi psikis remaja. Kematangan secara seksual membuat remaja menjadi mudah terangsang akan hal-hal yang berbau seksualitas karena dorongan seksual yang meningkat. Bagi sebagian besar remaja, fenomena seks dunia maya ini dianggap masih sangat tabu dan merupakan perilaku seksual yang tidak lazim. Namun ada juga yang menganggap perilaku ini merupakan suatu cara yang paling aman untuk menyalurkan hasrat seksualnya terutama bagi mereka yang belum memiliki pasangan. Hal inilah yang kemudian memicu perbedaan sikap diantara kaum muda tersebut (Pribadi dan Putri, 2009). Fakta menunjukan ternyata usia berkaitan dengan sikap positifnya remaja melakukan cybersex. Penelitian Pribadi dan Putri (2009) mengungkapkan data yang diperoleh berdasarkan deskripsi subjek yang di dasarkan pada usia menunjukan bahwa sikap terhadap seks dunia maya pada subjek yang berusia antara 21-24 tahun lebih tinggi dibanding subjek yang berusia 18-21 tahun atau 25-30 tahun. Rimington (2008) menyebutkan dalam penelitiannya bahwa usia 21-24 tahun telah masuk ke dalam kategori sexually compulsivity. Sexually compulsivity adalah perilaku seksual yang kompulsif, dimana perilaku seksual ini merupakan lanjutan dari cybersex yang berkonsekuensi terhadap kehidupan nyata (Delmonico, dalam Laws \& O'Donohue, 2008). Piaget (dalam Santrock, 2001) mengatakan bahwa remaja termotivasi untuk memahami dunia karena perilaku adaptasi secara biologis mereka. Usia 12 tahun keatas masuk kedalam tahap operasional formal, dimana remaja sudah mampu menalar secara abstrak dalam situasi 
yang menawarkan beberapa kesempatan untuk melakukan penalaran hipotesis dan berpikir proposional. Artinya saat remaja dihadapkan pada suatu permasalahan maka remaja akan mencari jalan keluar dengan memprediksi apa yang mungkin akan terjadi jika suatu tindakan diambil. Hal inilah salah satu alasan mengapa remaja melakukan cybersex. Rasa ingin tahu yang besar dan gelora akan seksualitas menjadikan remaja mengakses konten seksual melalui internet dengan beberapa alasan diantaranya mudah diakses, biaya yang dikeluarkan sedikit, dan aman dari penyakit menular seksual (Sari \& Purba, 2012).

Dalam penelitian ini didapatkan responden mengakses situs pornografi melalui media handphone pribadi yang dimilikinya. Berdasarkan hasil penelitian yang dilakukan Ikhsan (2009) menyebutkan bahwa kepemilikan handphone berpengaruh terhadap perilaku seksual remaja SMA. Widyastuti (2011) mengatakan faktor yang menyebabkan remaja ingin mengakses situs pornografi diantaranya ketersediaan fasilitas untuk mengakses.

Sarwono (2012) menyatakan bahwa anak yang beranjak remaja cenderung melakukan aktifitas-aktifitas seksual prasenggama seperti melihat buku atau film porno, berpacaran, berciuman dan sebagainya. Hasil penelitian ini menunjukkan sebanyak $63,8 \%$ responden berpacaran, 55,4\% responden pernah berpelukan, 54,6\% responden pernah mencium pipi/kening pasangan, 44,6\% berciuman bibir, dan $32,3 \%$ responden pernah melakukan necking. Menurut Komalasari (2008) ciuman pada daerah-daerah tersebut dapat membuat imajinasi atau fantasi seksual berkembang serta menimbulkan keinginan untuk melanjutkan melakukan bentukbentuk perilaku seksual lainnya. Hal ini berarti bahwa tidak menutup kemungkinan siswa yang sekarang ini hanya melakukan ciuman bibir saja suatu saat nanti akan berlanjut ke bentuk-bentuk perilaku yang lebih berat seperti intercouse.

Kelemahan penelitian responden kurang terbuka terkait masalah sex dengan alasan malu.

\section{SIMPULAN}

hasil penelitian ini didapatkan bahwa remaja kecenderungan mengakses situs porno pada pada usia 15-17 tahun, remaja mengunjungi situs porno mengenai gambar-gambar waita cantik, seksi dan film BF, komunikasi dengan pacar melalui chating dan vidio call dengan membahasan sex, pelampiasan setelah menonton situs porno dengan pacar ciuman, berpelukan dan sampai nekcing, responden sering onani setelah 
menonton/ melihat situs porno, perasaan penasaran dan rasa ingin tahu yang menyebabkan responden ingin membuka situs porno, dalam seminggu responden mengakses 3-4 kali dan lamanya 1-2 jam perhari, setelah menonton situs porno responden merasa puas dan terhibur. Kelemahan penelitian ini responden kurang terbuka terkait masalah sex dengan alasan malu

\section{DAFTAR PUSTAKA}

Ainiyah, N. (2017). Membangun Penguatan Budaya Literasi Media dan Informasi Dalam Dunia Pendidikan. Jurnal Pendidikan Islam Indonesia, 6577.

Noni Novika Sari, Ridhoi Meilona Purba, 2012. Gambaran Perilaku cyber sex pada remaja pelaku cyber sex di Kota Medan. Vol 7, No. 2 hal. 62-73. Psikologia online Supariasa, dkk. Penilaian Status Gizi. Jakarta: Penerbit Kedokteran: ECG, 2002

Cooper, A., Scherer, C., Boies, S. C., \& Gordon, B. L. (1999). Sexuality on the internet from sexual exploration to pathological expression. Professional Psychology: Research and Practice, 30(2), 154-164.

Golberg, P. D. (2004). An exploratory study about the impacts that cybersex (the use of the internet for sexual purposes) is having on families and the practices of marriage and family therapists. Tesis master yang tidak dipublikasikan, Virginia Polytechnic Institute and State
University, Falls Church, Virginia, U.S.A.

Ike Agustina, Fauzan Hafiza, 2013. Religiolitas dan perilaku cyber sex pada kalangan mahasiswa. Psikologika online volume 18 , nomer 1

Laws, D.R. \& O’Donohue, W.T. 2008. Sexual Deviance: Theory, assessment, and Treatment. New York: Guilford Press

Pribadi, S. Adjie dan Putri, D. Eka (2009). Perbedaan Sikap terhadap Seks Dunia Maya Pada Mahasiswa ditinjau dari Jenis Kelamin. Jurnal Universitas Gunadarma, Vol. 3. Oktober

Sari, N. Novika dan Purba, R. Meilona. 2012. Gambaran Perilaku Cybersex pada Remaja Pelaku Cybersex di Kota Medan. Jurnal Psikologia-Online, Vol. 7. No. 2, hal. 62-73.

Burhan, Bungin. 2013. Pornomedia Sosiologi Media, Konstruksi Sosial Teknologi Telematika, dan Perayaaan Seks di Media Massa. Jakarta: Rineka Cipta. 